\title{
Effective Communication Strategy with Community and Landowner in the Construction of High Voltage Power Transmission Line in Peninsular Malaysia
}

\author{
Kho Mei Ye ${ }^{1}{ }^{*}$, Mohd Suhaimi Mohd Danuri ${ }^{1}$, Othman Mohamed ${ }^{1}$, Nor Eliza \\ binti Selamat
}

*Department of Quantity Surveying, University of Malaya, Kuala Lumpur, Malaysia

Email: meiye@um.edu.my

\begin{abstract}
Power transmission system has been designed as an overhead lines constructed with lattice towers or monopoles; or as underground cables to transmit electricity supply from power plant to consumers. In order to meet the incremental demand of power supply, transmission networks require upgrading works and the construction of more overhead tower or monopole. This paper presents the implication of the community and landowner concerns on the effects of high voltage power transmission overhead lines construction in Peninsular Malaysia. Quantitative approach was applied in this research by distributing questionnaires survey to the targetted respondents. Language, culture, perception, knowledge and other factors such as political influence were significance variables which can affect effective communication strategy in the construction of high voltage power transmission lines in Peninsular Malaysia. Therefore, it is important to have an effective communication between all parties to generate positive outcome in supporting the progressive construction of the high voltage power transmission overhead lines.
\end{abstract}

Keywords: Communication Strategy, Community, Landowner, Construction, High Voltage Power Transmission Line

\section{INTRODUCTION}

High voltage power transmission is an important part of a power supply system. The power generated from power plant requires a transmission system to transmit electricity supply to consumers. According to Tenaga Nasional Berhad (TNB), high voltage power transmission in Malaysia comprise of $500 \mathrm{kV}, 275 \mathrm{kV}$ and $132 \mathrm{kV}$ voltage. These are either designed as overhead line erected with lattice towers or monopoles; or as underground cables which are mostly laid within densely populated area (Zulkifli \& Sivadass, 2006). 
Based on the Peninsular Malaysia Electricity Supply Report issued by Energy Commission in year 2014, the electricity growth in Malaysia was recorded at 16,562MW. This figure exceeds the initial 2013 forecast of 16,324MW and year 2012 records of 15,826MW by a percentage of $1.5 \%$ and $4.7 \%$ respectively. Electricity consumption per capita has increased from $1,101 \mathrm{kWh}$ per person in 1990 to 3,902kWh per person in 2012 with annual growth of $5.9 \%$ over the period of 22 years (Energy Commission, 2014).

In reference to the decision given by Court of Appeal in 2009 (court case W-02-1069-07), the protest from the landowners was caused by inadequate in monetary compensation for the land acquisition and in addressing the negative perception of electromagnetic field effects of the transmission overhead lines which is near the residence area vicinity. This project was only $98 \%$ completed, with the remaining 2\% was completed later on in December 2007 due to the arising dispute. The remaining $2 \%$ of uncompleted work was caused by land dispute. This problem has affected the 1 kilometer route length of the Central Area Reinforcement (CAR) project which comprises of a total of five transmission spans and four lattice towers spanning over the lands of Kampung Sungai Terentang (Energy Commission, 2014).

\section{THE IMPORTANCE OF EFFECTIVE COMMUNICATION STRATEGY}

The construction of power transmission overhead lines have faced tremendous objections from the landowner such as inadequate monetary compensation for land acquisition and its environmental impact. Land acquisition has been perceived as an huge obstacle to the progress of any infrastructure project (Rathbone \& Redrup, 2014). Disagreement between the utility company and the landowners is inevitable when monetary compensation has been seen as inadequate and their daily life was affected. A study by Alias and Daud (2006) have found that the compensation amount for the land acquisition was against the will of the land owner as stipulated in the Malaysian law. Therefore, Alias and Daud (2006) have suggested the need to review the factor of monetary compensation. This research will further explore the key elements in developing effective communication strategies as a crucial factor in project management especially for the construction of overhead power transmission lines. Apart from this, this study will also address the issue of project delays in the construction of a high voltage power transmission overhead lines.

In fulfillment of the rising demand of the industry and consumers' needs in generating and transmitting electricity, the construction of high voltage power transmission line which requires substantial land for its corridor has caused several disadvantages to the public and its surroundings. The usage of land for the construction of high voltage power transmission lines can caused noise pollution, and also affected the area concerned to be visually unattractive. The construction of this power transmission lines will also deem to create potential risk for the health and safety of the inhabitants (Furby, Slovic, Fischhoff \& Gregory, 1988). Furby et al. (1988) research have highlighted severe conflicts due to the public opposition on high voltage power transmission overhead lines in the United States of America from the 1960s to 1980s. The research by Furby et al. (1988) have found that the opposition to the construction of high voltage 
power transmission overhead lines have caused major loss to power utilities companies due to delays in achieving regulatory approval, litigation fees and vandalism. The amount of disputes incurred have shown that the construction plan may have overlooked the public's concern on this matter. Droge and Messer (2012) have conducted a study to understand the public resistance to energy technologies. It was found that the public resistance to the progress of energy development projects was excruciating and complicated. This study also concluded that the public resistance can be overcome by formulating an effective communication strategy.

This research aims to determine how effective communication strategies can help to overcome the resistance from the local community and landowner towards the construction of high voltage power transmission overhead lines. The impact of the construction of overhead power transmission lines on the project performance will be identified and the strategic communication plan will be formulated as a reference for a power utility company or grid owner in managing the protest from community or landowner.

Roland Berger's toolkit is fully accessible to any user via a public web-interface and beneficial to all stakeholder groups to collectively raise public acceptance for any specific grid project in a multi-stakeholder dialogue. The toolkit comprises of diverse stakeholders involved, project stages, communication channels, communication formats and contents. In each of the categories, it outlines the specific profiles of different stakeholders or different project stages (Roland Berger, 2014). Among the identified stakeholders are the adjacent communities and landowners. Figure 1 is an overview of the toolkit structure:

\begin{tabular}{|c|c|c|c|c|}
\hline Stakeholders & Stages & Channels & Formats & User guides \\
\hline $\begin{array}{l}>\text { TSOs } \\
>\text { European institutions } \\
>\text { Nat'URe. policy makers } \\
>\text { Environmental NGOS } \\
>\text { Regulators } \\
>\text { Permitting authorities } \\
>\text { Power producers } \\
>\text { Industrial consumers } \\
>\text { Private consumers } \\
>\text { Adjacent communities } \\
>\text { Local elected officials } \\
>\text { Land owners } \\
>\text { Local citizens' } \\
\text { initiatives } \\
>\text { Experts/Academia } \\
>\text { Media }\end{array}$ & $\begin{array}{l}>\text { Determination of need } \\
>\text { Project preparation } \\
>\text { Spatial planning } \\
>\text { Permitting } \\
>\text { Construction } \\
>\text { Operation } \\
\text { Contents } \\
>\text { Project location } \\
>\text { Project timetable } \\
>\text { Technical details } \\
>\text { Compensation } \\
\text { measures } \\
>\text { Information on project } \\
\text { developers }\end{array}$ & $\begin{array}{l}>\text { Public space events } \\
>\text { Town hall meeting } \\
>\text { Roundtable } \\
>\text { World Café } \\
>\text { Closed-door meeting } \\
>\text { Citizens helpline } \\
>\text { Project information } \\
\text { office } \\
>\text { Doorstep visits } \\
>\text { Field visit } \\
>\text { Project website } \\
>\text { Social media } \\
>\text { Mediation }\end{array}$ & $\begin{aligned} &> \text { Brochure/Flyer/Leaflet/ } \\
& \text { Fact sheet } \\
&> \text { Presentation } \\
&> \text { Exhibition } \\
&>\text { Infographics }\end{aligned}$ & $\begin{array}{l}>\text { Storyline and } \\
\text { framework for } \\
\text { messaging in grid } \\
\text { extension projects } \\
\quad>\text { WHY? } \\
\quad>\text { WHAT? } \\
>\text { WHERE? }\end{array}$ \\
\hline
\end{tabular}

Figure 1: Overview of toolkit

(Source: Roland Berger Strategy Consultant Report, 2014: 5)

Table 1 and 2 have shown the extracted content of the Roland Berger's toolkit on the strategies with adjacent communities and landowners as identified in the Roland Berger's research. With 
reference to the Roland Berger's toolkit, it is hoped that some of these essential elements can assist in the successful development of power grid project in Malaysia. This research will also improve the project communication by having constructive multi-stakeholder dialogue at the local level for any development of power grid project in Malaysia.

Another study on effective communication strategies for power transmission lines project was conducted by the Roland Berger Strategy Consultant. The objective of this research by Roland Berger Strategy Consultant was to develop the European strategy to raise the public acceptance on the development of power transmission grid infrastructure project. This research aims to cater the need of crucial stakeholders of power grid development projects across Europe such as the the Transmission System Operators, NGOs, public authorities and local communities. The research outcome of this project has higlighted an online toolkit that contains the element of communication strategy and stakeholder involvement to raise public acceptance and participation of community for individual grid infrastructure development projects in Europe. This toolkit comprises of various stakeholders, project stages, communication channels, communication formats and contents. In each of this categories, it has outlined the specific profiles of different stakeholders or different project stages for the identified stakeholders scuh as the adjacent communities and landowners. The toolkit sections as tabulated in Table 1 and Table 2 represent different elements to systematise and organise a stakeholder and communication strategy of any transmission grid project under development.

Table 1: Roland Berger Toolkit for Communication Strategies in Power Grid Projects Adjacent Community

\begin{tabular}{|c|c|}
\hline Stakeholder role in grid projects & $\begin{array}{c}\text { Adjacent } \\
\text { Communities }\end{array}$ \\
\hline $\begin{array}{l}\text { Adjacent communities are the citizens who live in } \\
\text { power grid project under development. All stakeh } \\
\text { informing local communities over the project cyc } \\
\text { maximizing room to maneuver for joint decision } \\
\text { affected. This starts with recurring explanations o } \\
\text { backdrop of national legislation that governs the pla } \\
\text { The role of adjacent communities can be to particip } \\
\text { grid project, for example in terms of local conditio } \\
\text { routing. Their part in a successful multi-stakehold } \\
\text { implementation with high public acceptance by be } \\
\text { configuration of the project. In this regard, local citiz } \\
\text { expertise for transmission grid owners (TSO) and pr } \\
\text { on in the process as soon as route alternatives with } \\
\text { micro-planning of power lines, especially the defini } \\
\text { for overhead lines are jointly identified with membe }\end{array}$ & $\begin{array}{l}\text { directly adjacent to the } \\
\text { pecial attention towards } \\
\text { inities for dialogue and } \\
\text { level where people are } \\
\text { themselves against the } \\
\text { g process. } \\
\text { lementation of a power } \\
\text { hoice of technology and } \\
\text { ntribute to the project's } \\
\text { ely involves in the local } \\
\text { ource of knowledge and } \\
\text { t should be tapped early } \\
\text { lor are discussed so that } \\
\text { he positioning of pylons } \\
\text { nunities. }\end{array}$ \\
\hline
\end{tabular}




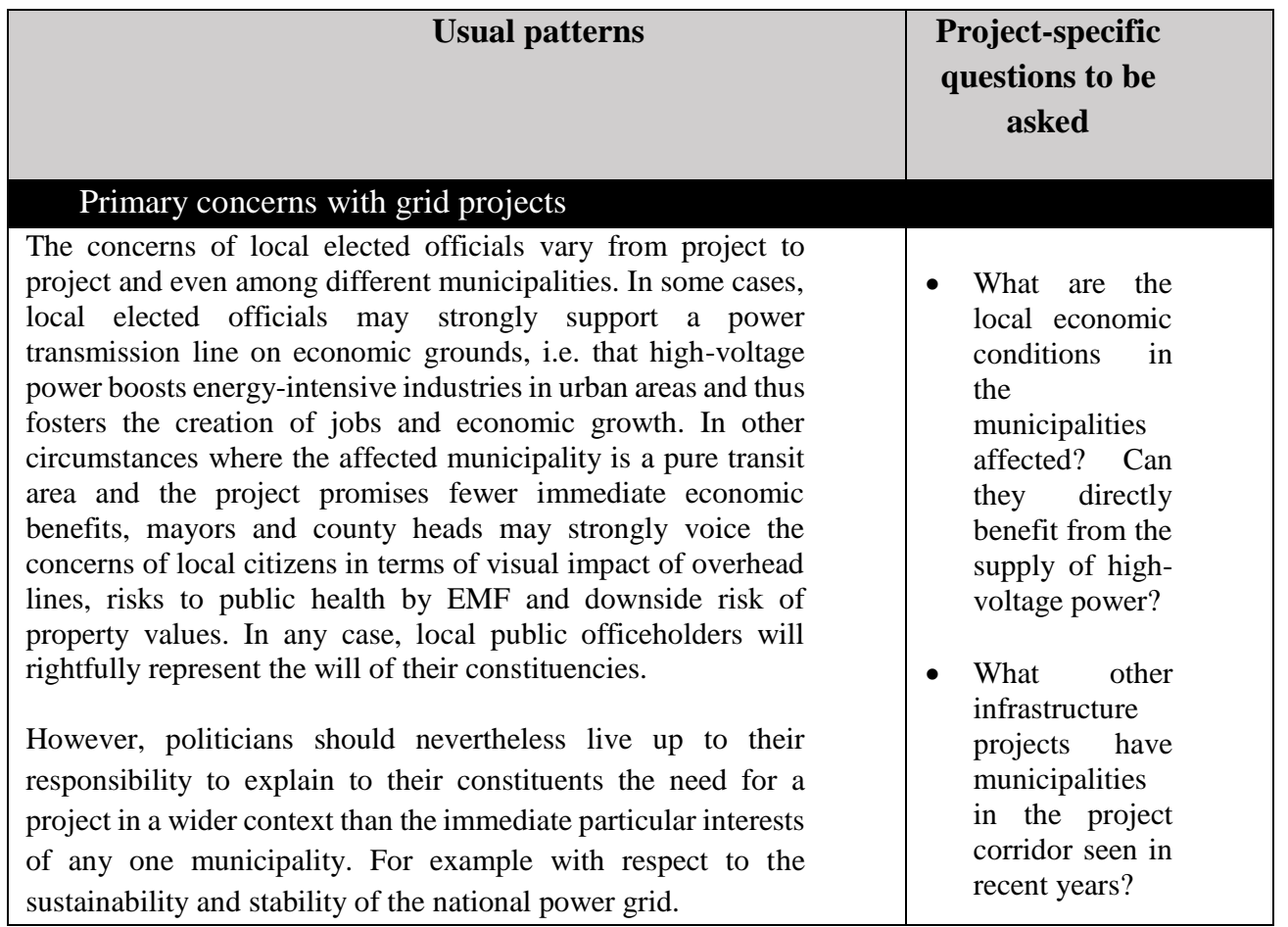

\section{Individuals within stakeholder organisation/entities}

Among local elected officials, several specific positions are particularly important to be reached out to in the context of communication and stakeholder integration efforts. These officials include mayors or the elected heads of the municipal administration as the main representatives, but also the elected heads of committees in city parliaments or county assemblies in charge of infrastructure, environment, energy and economic policy.

Project stages for engagement

Determination of need

At the very inception of a grid project when the need for a connection between a starting and an end point is established, local elected officials can be important multipliers of information. At this stage, large scale involvement of local communities is difficult and hardly feasible due to the lack of concreteness of the project especially in terms of location. Consequently, it is crucial to identify and address key individuals in potentially affected municipalities that can be messengers to wider audiences.

As elected representatives of these communities, mayors and county heads with their administrations are the first multipliers in this regard that come to mind. For example, mayors should be invited to participate in early consultation procedures when national grid scenarios are developed by regulators and policy makers.

Project preparation
- Who are the mayors of major cities in the pipeline corridors?

- Who are other key elected officials in the municipal parliaments?

- Who are Who are the mayors of major cities in the pipeline corridors that can reach large audiences with early project information?

- What publication outlets of municipal administrations can be used to disseminate early project information? 
The involvement of local elected officials as democratically elected representatives and spokespersons of their municipalities becomes even more important as the project progresses. As different route alternatives and possible corridors are specified, it becomes ever more central to involve municipalities even though there is still insufficient concreteness as regards the location for large-scale stakeholder integration activities to take place at the local level.

\begin{tabular}{|c|c|}
\hline \multicolumn{2}{|l|}{ Project stages for engagement } \\
\hline $\begin{array}{l}\text { Determination of need } \\
\text { At the very inception of a grid project when the need for a } \\
\text { connection between a starting and an end point is established, local } \\
\text { elected officials can be important multipliers of information. At } \\
\text { this stage, large scale involvement of local communities is difficult } \\
\text { and hardly feasible due to the lack of concreteness of the project } \\
\text { especially in terms of location. Consequently, it is crucial to } \\
\text { identify and address key individuals in potentially affected } \\
\text { municipalities that can be messengers to wider audiences. } \\
\text { As elected representatives of these communities, mayors and } \\
\text { county heads with their administrations are the first multipliers in } \\
\text { this regard that come to mind. For example, mayors should be } \\
\text { invited to participate in early consultation procedures when } \\
\text { national grid scenarios are developed by regulators and policy } \\
\text { makers. }\end{array}$ & $\begin{array}{l}\text { - Who are the mayors of } \\
\text { major cities in the pipeline } \\
\text { corridors that can reach } \\
\text { large audiences with early } \\
\text { project information? } \\
\text { - What publication outlets } \\
\text { of municipal } \\
\text { administrations can be } \\
\text { used to disseminate early } \\
\text { project information? }\end{array}$ \\
\hline $\begin{array}{l}\text { Project preparation } \\
\text { The involvement of local elected officials as democratically } \\
\text { elected representatives and spokespersons of their municipalities } \\
\text { becomes even more important as the project progresses. As } \\
\text { different route alternatives and possible corridors are specified, it } \\
\text { becomes ever more central to involve municipalities even though } \\
\text { there is still insufficient concreteness as regards the location for } \\
\text { large-scale stakeholder integration activities to take place at the } \\
\text { local level. }\end{array}$ & $\begin{array}{l}\text { - Who are the mayors of } \\
\text { major cities in the pipeline } \\
\text { corridors that can reach } \\
\text { large audiences with early } \\
\text { project information? } \\
\text { - What publication outlets } \\
\text { of municipal } \\
\text { administrations can be } \\
\text { used to disseminate early } \\
\text { project information? } \\
\text { of major cities in the } \\
\text { pipeline corridors that can } \\
\text { reach large audiences } \\
\text { with early project } \\
\text { information? What } \\
\text { publication outlets of } \\
\text { municipal administrations } \\
\text { can be used to disseminate } \\
\text { early project information? }\end{array}$ \\
\hline $\begin{array}{l}\text { Spatial planning and Permitting } \\
\text { During the spatial planning and permitting stages, the } \\
\text { multiplying role of local elected officials function is } \\
\text { extended to a formal role as provider and distributor of } \\
\text { information. Municipalities often receive information }\end{array}$ & $\begin{array}{l}\text { - What are important } \\
\text { documents in the legally } \\
\text { mandated spatial planning } \\
\text { and permitting procedures } \\
\text { that can be made available }\end{array}$ \\
\hline
\end{tabular}


coming from permitting authorities at national or regional level that they are required to pass on and make available to local communities.

This role is particularly crucial because members of local communities have to be able to count on their representatives to pass on project-related information like planning documentation (e.g. maps of line corridors, technical specifications etc.).

In addition, local elected officials can take a leading role in the negotiations for compensation measures as representatives of the adjacent communities.

Spatial planning and Permitting

In their capacity as broker between project developers and adjacent communities they might also be involved in the organisation of local events for information, dialogue and participation with regards to the project

\section{Adequate channels for participation/cooperation}

Closed-door meetings

In advanced phases of the project, mayors and county heads should be engaged by project sponsors in closed-door meetings where they are individually briefed on the potential implications of a grid project on their municipality.

Local elected officials are an integral participant of multistakeholder roundtables during the spatial planning or permitting stage of the project. In order to foster a constructive, collaborative working atmosphere and share the resource expenditure for stakeholder integration activities, local elected officials should contemplate their own or at least a joint organization of roundtables. Especially in more conflict-intense project environments mayors can play the role of mediators and moderators that bring everyone to the table consisted of TSOs, Adjacent communities and their local citizens' initiatives, permitting authorities and policy makers.

\section{Country-specific examples}

Germany, Austria and Spain

The involvement of municipalities in the stakeholder integration process for power grid projects is especially important in federalist countries where comparatively more decision making power is concentrated at the municipal level. Here, mayors are often more than mere implementers of decisions made at the national level and by procedure have to be part of the process.

(Source : Revised Final Report, Study Regarding Grid Infrastructure Development: European Strategy for Raising Public Acceptance, 2014: 54)

Table 2: Roland Berger Toolkit for Communication Strategies in Power Grid Projects Landowners to local stakeholders via municipal administration?

- What can TSOs do to ensure that municipal administrations indeed pass on information and make it available to larger local audiences?
- Who are the mayors of major cities in the pipeline corridors or other important individuals in municipal administrations that should be briefed in a meeting?

- Can roundtables be jointly organised by the TSOs, permitting authorities and municipalities?

- To what extent can the working atmosphere of the Roundtables contribute finding compromises with local affected stakeholders?

\section{$\bullet$}




\begin{tabular}{|c|c|}
\hline Stakeholder role in grid projects & Landowners \\
\hline \multirow{2}{*}{\multicolumn{2}{|c|}{$\begin{array}{l}\text { Landowners are stakeholders of power grid projects whose physical property is crossed by the } \\
\text { overhead power line or underground cable. Unlike adjacent communities which are indirectly } \\
\text { affected by the project e.g. by its visual impact on the surrounding countryside, landowners directly } \\
\text { deal with pylons constructed on their premises or cable corridors passing over their property. By } \\
\text { varying means of national legislation or lack thereof, landowners are typically compensated } \\
\text { financially for the use of their land in one way or another, depending on their cooperation and } \\
\text { agreement to the use of land by TSOs to construct the grid connection. In case of failure to reach an } \\
\text { agreement, land usage issues are normally settled in court where expropriation of landowners may } \\
\text { be the final means of dispute settlement. } \\
\text { Given the means of compensation for landowners available by law and in practice, Landowners } \\
\text { usually become constructively engaged with other stakeholders of the project. Moreover, } \\
\text { landowners can play a crucial role in defining the precise routing of a grid section. This is especially } \\
\text { true for the positioning of pylons for overhead power lines because they possess the best knowledge } \\
\text { of local premises and because they can determine where a pylon may be least detrimental to ongoing } \\
\text { economic activities, such as farming. For TSOs, it is hence more than worthwhile to engage } \\
\text { landowners and consider their input and opinion on the construction of the power line. }\end{array}$}} \\
\hline & \\
\hline Usual patterns & $\begin{array}{l}\text { Project-specific questions to be } \\
\text { asked }\end{array}$ \\
\hline \multicolumn{2}{|l|}{ Primary concerns with grid projects } \\
\hline $\begin{array}{l}\text { Landowners' primary concern with grid projects } \\
\text { is the effects that the physical infrastructure } \\
\text { (underground cables, pylons for overhead lines } \\
\text { etc.) will have on their property and its economic } \\
\text { usability. }\end{array}$ & $\begin{array}{l}\text { - What kinds of pylons are used by the } \\
\text { project at which section? } \\
\text { How do the chosen pylons affect the } \\
\text { property and land on the ground, e.g. } \\
\text { in terms of their baseplates? }\end{array}$ \\
\hline \multicolumn{2}{|l|}{ Topography within stakeholder group } \\
\hline $\begin{array}{l}\text { Landowners can be private individuals such as } \\
\text { farmers or households with large landholdings, } \\
\text { but also include municipalities and other } \\
\text { statutory bodies such as churches or dioceses. } \\
\text { While landowners are generally equal from a } \\
\text { stakeholder perspective, farmers associations are } \\
\text { important organizations that channel the interests } \\
\text { of multiple land owning farmers affected in order } \\
\text { to participate in the stakeholder dialogue most } \\
\text { importantly with the TSO. At stakeholder } \\
\text { meetings (e.g. roundtables) farmers associations } \\
\text { may thus be indispensable participants, } \\
\text { particularly when dialogue occurs at a higher } \\
\text { level and at an earlier project stage. }\end{array}$ & $\begin{array}{l}\text { - What does the topography of } \\
\text { Landowners in the specific corridor of } \\
\text { interest look like? } \\
\text { Who are the large-scale Landowners } \\
\text { to which large parts of the affected } \\
\text { area belong? } \\
\text { Are individual Landowners like } \\
\text { farmers organized in associations or } \\
\text { other institutional forms at a local or } \\
\text { regional level? }\end{array}$ \\
\hline \multicolumn{2}{|l|}{ Project stages for engagement } \\
\hline $\begin{array}{l}\text { Project preparation } \\
\text { During early project stages it is both absolutely } \\
\text { recommendable and practically most feasible to } \\
\text { engage the important stakeholder group of } \\
\text { Landowners via representative associations e.g. } \\
\text { the national and regional farmers' associations. } \\
\text { Such associations should be part of information, } \\
\text { consultation and participation events during the } \\
\text { preparation of the Spatial planning when } \\
\text { different corridor alternatives are identified and } \\
\text { put on the short list. }\end{array}$ & $\begin{array}{l}\text { - Who are regional representatives } \\
\text { of farmers' associations that } \\
\text { would be best suited to } \\
\text { participate in stakeholder } \\
\text { involvement events at a very } \\
\text { early stage of the project? }\end{array}$ \\
\hline
\end{tabular}


Spatial planning

During the spatial planning, specific corridors are analyzed and benchmarked with each other in order to arrive at a preferred route for the power grid, which will be submitted to the relevant authorities for permitting. During this phase, the knowledge of the Landowners about their own property as well as their preferences for microrouting (especially regarding the positions of pylons) should be tapped and well considered by the TSO. In the end, the route submitted for permitting should have included a maximum of individual input from the different property holders. Moreover, the legal procedure for financial compensation has to be clearly communicated to landowners individually, so that roles, responsibilities, timelines and documentation needs are transparent from the start.

\section{Permitting}

During the Permitting stage, it is important to keep Landowners informed about the ongoing process and potential changes to the routing as they arise from mandatory consultation procedures and input given by the Permitting authorities. Finally, compensation mechanisms have to be activated so that Landowners receive financial compensation before their land is first being accessed by the TSO and its contractors.

\section{Construction}

during the construction of the grid project. Specifically, they should communicate as early as possible the precise construction schedule and activities that are to take place on the landowners' ground and property as well as the repercussions that the construction activities will have on the economic use of the affected land.

\section{Adequate channels for participation/cooperation}

Doorstep visits and other direct contact

Several TSOs across Europe have made the experience that any form of direct contact with landowners via mail, telephone and/or even personal doorstep visits is the best way to ensure that every one is involved in the dialogue between TSOs, permitting authorities and landowners.

On an ever growing number of power grid projects across Europe, TSOs undertake the effort to speak with each and landowner along the grid route individually, in order to assess whether and how the micro-routing of the line can be solved best.

Roundtable

Moreover, Landowners should be participating in multi-stakeholder Roundtables that occur at the level of sections of power lines during the Project
- How can individual landowners be addressed individually to discuss the micro routing?

- How can the TSO obtain an overview of cadastral information on the Landowners that are affected by the preferred route?
- What essential steps of the legal permitting process are most important for landowners?

- How can they be kept informed throughout the ongoing permitting procedure?
- about upcoming construction activities?
- How can the impact on the economic use of the land be minimized during the construction stage?

- What are the terms and conditions of jointly deciding the microrouting of the power line, e.g. in terms of positioning the pylons of an overhead line?

- How much room to maneuver does the TSO have in a specific section of the project? Why is that the case? 


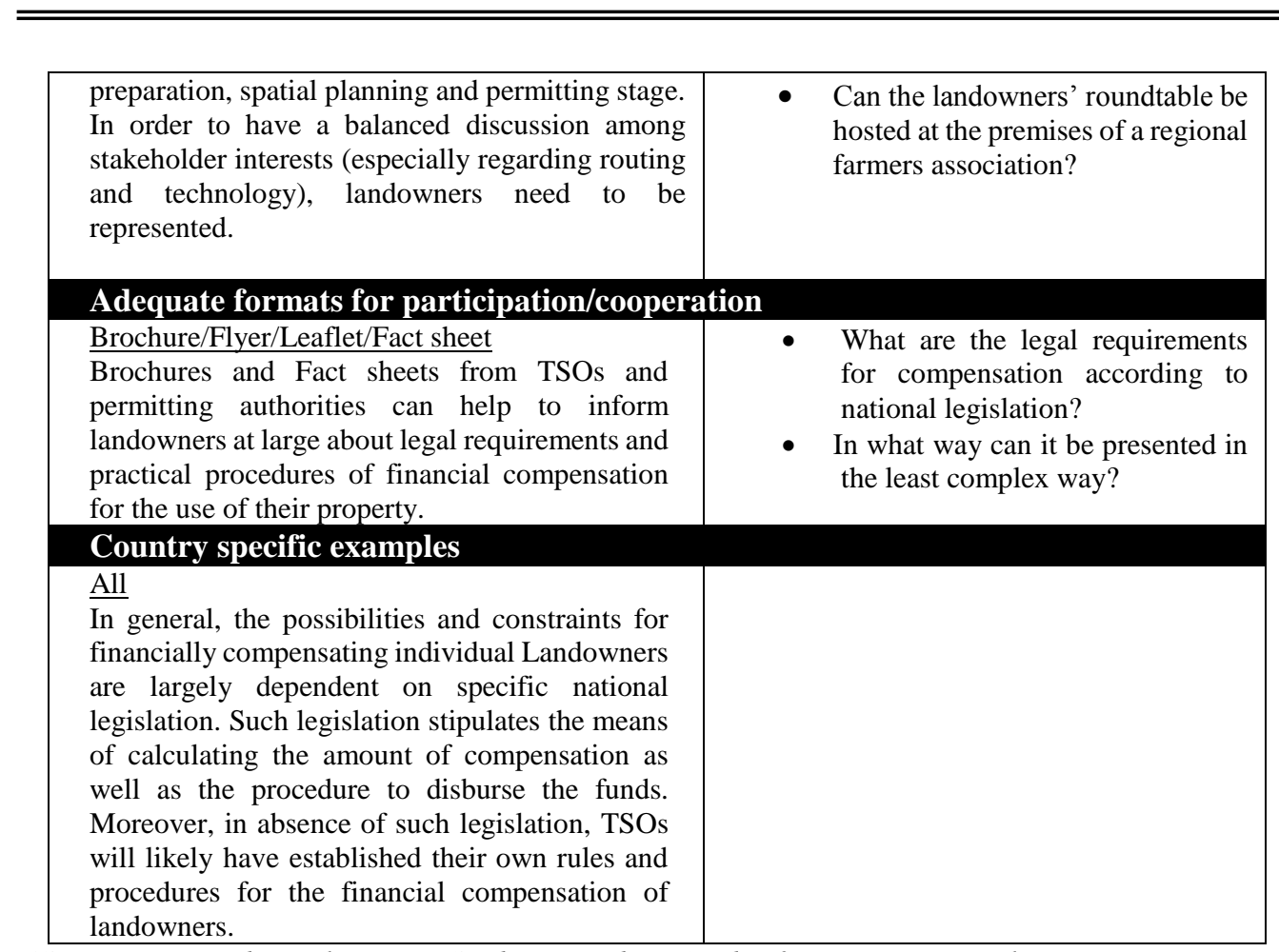

(Source: Revised Final Report, Study Regarding Grid Infrastructure Development: European Strategy for Raising Public Acceptance, 2014: 68)

\section{RESEARCH METHODOLOGY}

The aim of this study is to explore the shortcomings of communication between all relevant parties and to formulate effective communication strategies with the landowner in overcoming disputes or disagreements.

The research methodology of this study is divided into two stages. The first stage involves literature review that serves as an exploratory phase to provide an insight of the problem and its implication. Data was collected from archives, reports and previous researches to identify the implications of effective communication strategy . The second stage is the distribution of questionnaires survey to the professional personnel involved in the construction of high voltage power transmission overhead lines. Quantitative approach was adopted for this study. According to Cresswell and Clark (2007), quantitative research intends to test a theory deductively to support or refute an idea. Quantitative methods will utilize literature to justify a problem statement and identify questions and make hypotheses (Cresswell \& Clark, 2007). 


\section{FINDINGS AND DISCUSSIONS}

\subsection{Sample Size and Response Rate}

57 questionnaires were distributed to the professional personnel involved in the construction of high voltage power transmission overhead lines and 24 responses were received. The response rate of this study is $42 \% .100 \%$ replies were received from face to face interaction ( 5 respondents) while 19 respondents replied through e-mail. Kinnear and Tayler (1987) stated that each study has its own considerations and therefore no sample size can be considered as statistically optimal. The sample size for this study was based on the guidelines by Roscoe (1975). According to Roscoe (1975), a sample size larger than 30 and less than 500 members is adequate for most of the research studies. However, experimental research studies with tight experimental control, successful research is possible with sample as small as 10 to 20 members in size (Roscoe, 1975). Table 3 is the table produced by Krejcie and Morgan (1970: 608) to determine sample size based on work done by the National Education Association.

This study involved a total of 57 professional personnel which consisted of engineers, project managers and administrators. The sample size was considered effective based on the actual personnel involved with the construction of high voltage overhead transmission line was approximately 57 professionals based on the existing organization structure of the Transmission Division, TNB. As one of the core division in TNB, Transmission Division connected the electricity supply between the various power stations in the Peninsular of Malaysia and the distribution system to consumers via comprehensive transmission network (TNB Annual Report, 2013). The response rate of $42 \%$ was fairly acceptable for this small data sampling. The findings accumulated from the 24 respondents were deemed to be trustworthy as the respondents are directly involved and have hands on experience with the management of high voltage power transmission lines in Peninsular Malaysia.

In this study, non-probability sampling was used. Non-probability sampling is any technique in which samples are selected in some way not suggested by probability theory. However, it is worth to understand that this method does not permit any control over the representativeness of a sample (Babbie, 2007). Purposive sampling is a type of nonprobability sampling in which the units to be observed are selected on the basis of the researcher's judgment about which ones will be the most useful or representative (Babbie, 2007: 204). This study has employed purposive sampling. Based on the existing organization structure of the Transmission Division, TNB, the numbers of the actual personnel involved with the construction of high voltage overhead transmission line is approximately 57 professionals. Therefore, 57 respondents from Transmission Division, TNB were identified as the sample of this study (Babbie, 2007). 
Table 3: Required sample size

\begin{tabular}{|c|c|c|c|c|}
\hline $\mathrm{N}-\mathrm{n}$ & $\mathrm{N}-\mathrm{n}$ & $\mathrm{N}-\mathrm{n}$ & $\mathrm{N}-\mathrm{n}$ & $\mathrm{N}-\mathrm{n}$ \\
\hline $10-10$ & $100-80$ & $280-162$ & $800-260$ & $2800-338$ \\
\hline $15-24$ & $110-86$ & $290-165$ & $850-265$ & $3000-341$ \\
\hline $20-19$ & $120-92$ & $300-169$ & $900-269$ & $3500-346$ \\
\hline $25-24$ & $130-97$ & $320-175$ & $950-274$ & $4000-351$ \\
\hline $30-28$ & $140-103$ & $340-181$ & $1000-278$ & $4500-354$ \\
\hline $35-32$ & $150-108$ & $360-186$ & $1100-285$ & $5000-357$ \\
\hline $40-36$ & $160-113$ & $380-191$ & $1200-291$ & $6000-361$ \\
\hline $45-40$ & $170-118$ & $400-196$ & $1300-297$ & $7000-364$ \\
\hline $50-44$ & $180-123$ & $420-201$ & $1400-302$ & $8000-367$ \\
\hline $55-48$ & $190-127$ & $440-205$ & $1500-306$ & $9000-368$ \\
\hline $60-52$ & $200-132$ & $460-210$ & $1600-310$ & $10000-370$ \\
\hline $\mathbf{6 5}-\mathbf{5 6}$ & $210-136$ & $480-241$ & $1700-313$ & $15000-375$ \\
\hline $70-59$ & $220-140$ & $500-217$ & $1800-317$ & $20000-377$ \\
\hline $75-63$ & $230-144$ & $550-226$ & $1900-320$ & $30000-379$ \\
\hline $80-66$ & $240-148$ & $600-234$ & $2000-322$ & $40000-380$ \\
\hline $85-70$ & $250-152$ & $650-242$ & $2200-327$ & $50000-381$ \\
\hline $90-73$ & $260-155$ & $700-248$ & $2400-331$ & $75000-382$ \\
\hline $95-76$ & $270-159$ & $750-254$ & $2600-335$ & $100000-384$ \\
\hline
\end{tabular}

(Source: Krejcie \& Morgan, 1970: 608)

\subsection{Questionnaires Findings}

\subsubsection{Respodents' Demographic}

As shown in Figure 1, the respondents participated in this questionnaire survey came from different departments. Each department has its own responsibilities but was closely interrelated to support the management of the construction of overhead power transmission line. $50 \%$ of the respondents were mainly from the Engineering Department, followed by Asset Development Department at $29.2 \%$, Asset Management Department and Wayleave Department at $8.3 \%$ and Administration/Vice President Office at $4.2 \%$.

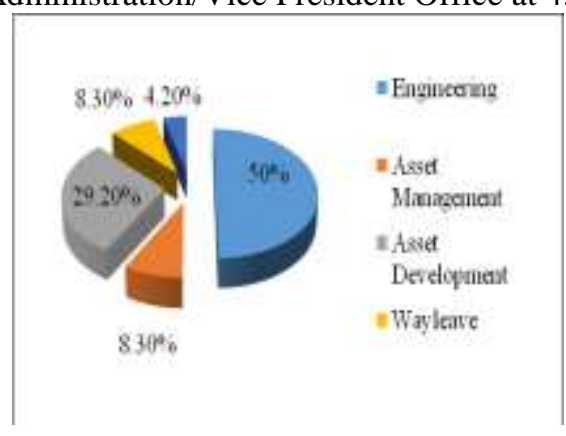

Figure 1: Respondent's department 
As shown in Figure 2, these respondents were vastly experienced personnel in this field of study. $37.5 \%$ of these respondents have 8 to 11 years of working experience, $29.2 \%$ have 11 years and above experience, $29.2 \%$ of them have 4 to 7 years of experience while only $4.2 \%$ was considered junior staff with 1 to 3 years of experience in the industry.

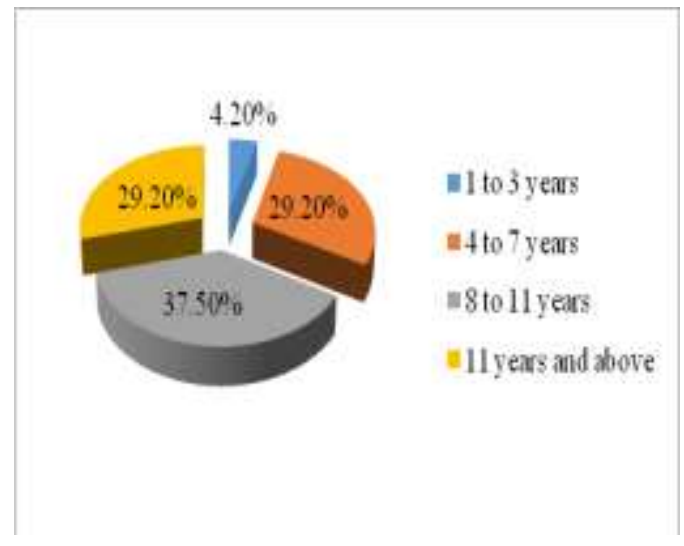

Figure 2: Respondents' working experience

As shown in Figure 3, 45.8\% of these respondents were Design Engineer followed by the Project Manager (41.7\%), Wayleave Officer (8.3\%) and General Administrator (4.2\%).

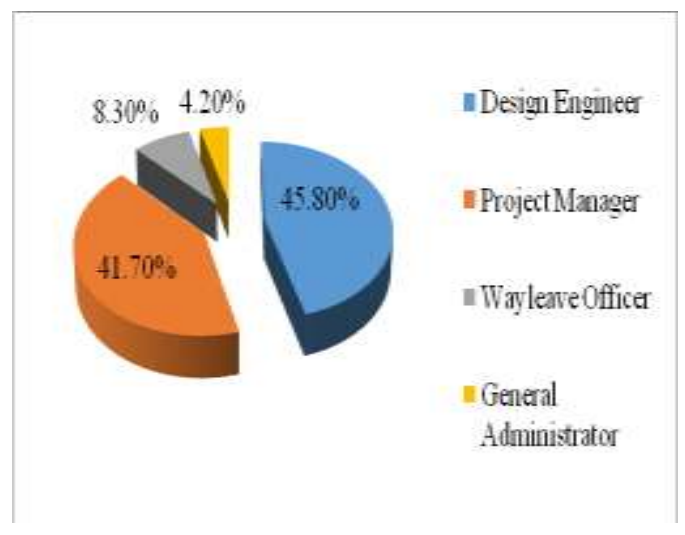

Figure 3: Respondents' roles

All respondents have encountered delay issues in their projects which they have been involved or currently working with. A total of $100 \%$ response rate from the targeted respondents have indicated the seriousness of delay issue in the construction of overhead power transmission lines. All of these respondents $(100 \%)$ have agreed that land acquisition and opposition from community and landowners were among the most critical factor of construction delay. As shown in Figure 4, all of them have came into consensus that the impact of objections from the community and landowners were severe ( $45.8 \%)$ and extremely severe $(54.2 \%)$. 


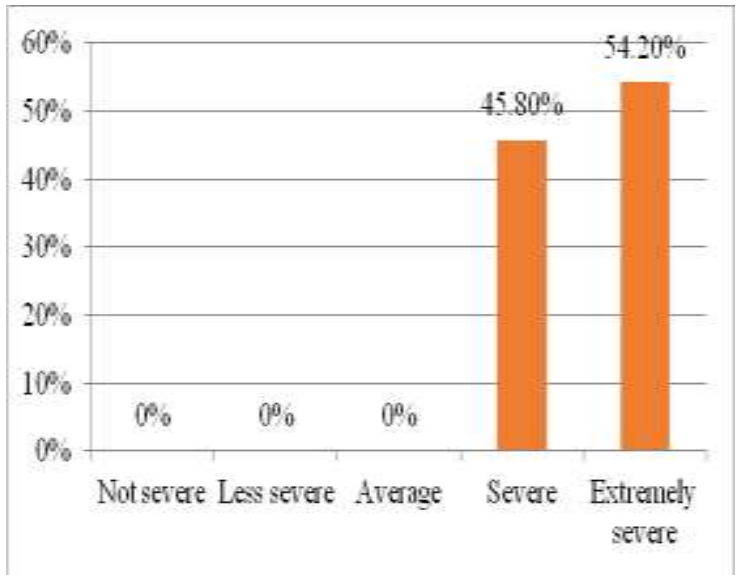

Figure 4: Severity of land acquisition and opposition from community and landowner to project success

A total of $75 \%$ respondents as illustrated in Figure 5 are aware that their company has instilled engagement programs with the local community and landowner as a key standard in the communication strategies.

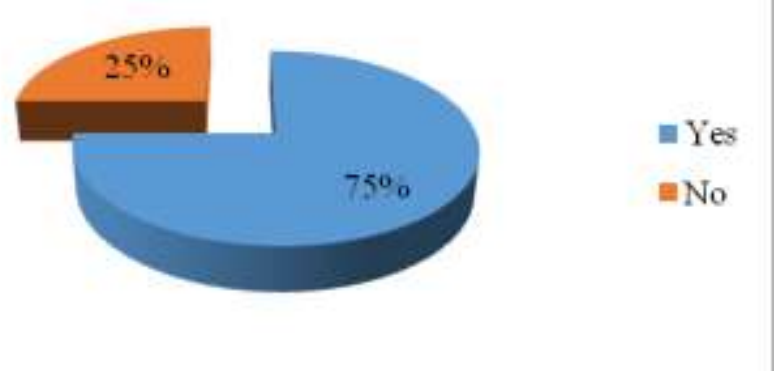

Figure 5: Awareness on engagement program

The engagement programs were namely project presentation to stakeholders on periodical basis, such as Corporate Social Responsibility (CSR) activities relating to community of affected areas and dialogues session. However, the success rate of these engagement programs are low as shown in Figure 6 which is only 33.33\%. 41.67\% believed that the engagement programs were unsuccessful and $25 \%$ of respondent believe it to be neutral. 


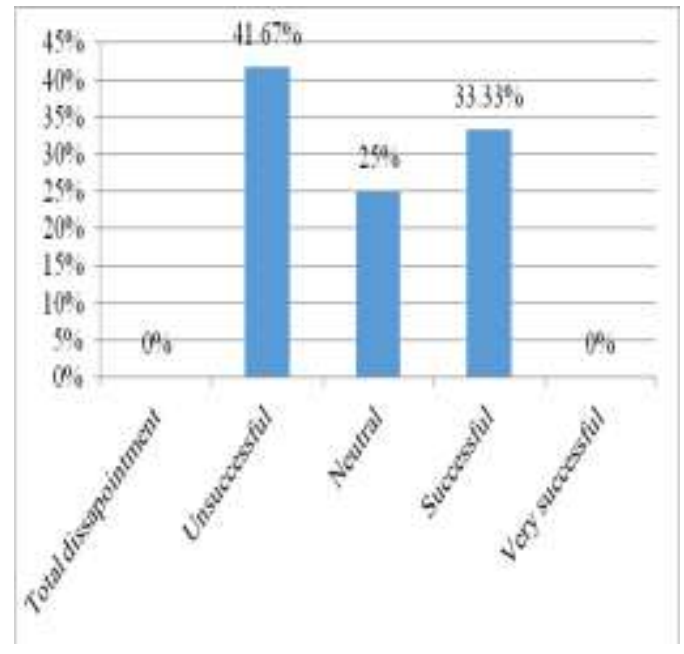

Figure 6: Success rating of engagement programs

Table 4 shows the frequency of respondent scoring and mean score for methods currently being used to communicate with community and landowner in conveying the projects information. From Table 2, it can be seen that face to face meeting (mean score of 4.38) is a regular practice and is followed by correspondence through letters and memos (mean score of 3.08), internet and website (mean score of 2.54), e-mail (mean score of 2.25), telephone (mean score of 1.62) and fax (mean score of 1.21).

Table 4: Communication methods used to communicate with community and landowner in conveying projects information

\begin{tabular}{|c|c|c|c|c|c|c|c|}
\hline \multirow{2}{*}{$\begin{array}{l}\text { Communication } \\
\text { Methods }\end{array}$} & \multicolumn{5}{|c|}{ Frequency of respondent scoring } & \multirow{2}{*}{$\begin{array}{l}\text { Mean } \\
\text { Score }\end{array}$} & \multirow[t]{2}{*}{ Rank } \\
\hline & 1 & 2 & 3 & 4 & 5 & & \\
\hline $\begin{array}{l}\text { Face to face } \\
\text { meeting }\end{array}$ & 1 & 2 & 8 & 13 & - & 4.38 & 1 \\
\hline Letters/ Memos & 1 & 5 & 12 & 3 & 3 & 3.08 & 2 \\
\hline $\begin{array}{l}\text { Internet and } \\
\text { website }\end{array}$ & 3 & 12 & 4 & 4 & 1 & 2.54 & 3 \\
\hline Email & 3 & 14 & 6 & 1 & - & 2.25 & 4 \\
\hline Telephone & 18 & - & 3 & 3 & - & 1.62 & 5 \\
\hline Fax & 21 & 2 & - & 1 & - & 1.21 & 6 \\
\hline
\end{tabular}

As shown in Figure 7, 50\% of respondents have the opinion that the effectiveness of communication strategies adopted in their company is moderately implemented, received setbacks and have caused delay to project execution. 


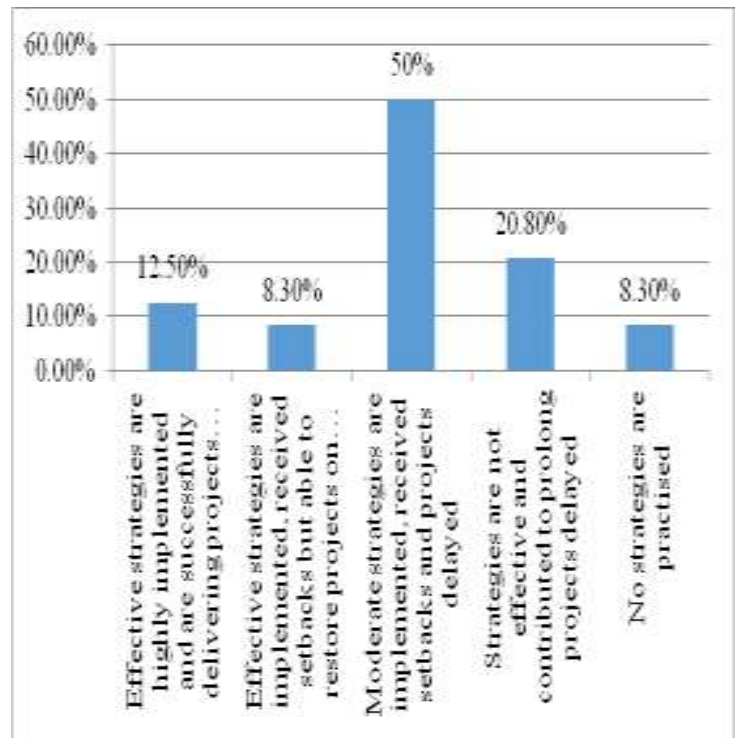

Figure 7: Effectiveness of communication strategies adapted

This study further explores the main factors which will influence communication to community and land owner. From the respondents' point of view (Figure 8), all factors listed are equally important. Additional remark was given to factors due to political influence as given by 13 respondents. The current political situation in Peninsular Malaysia is a sensitive issue and is not covered in this survey.

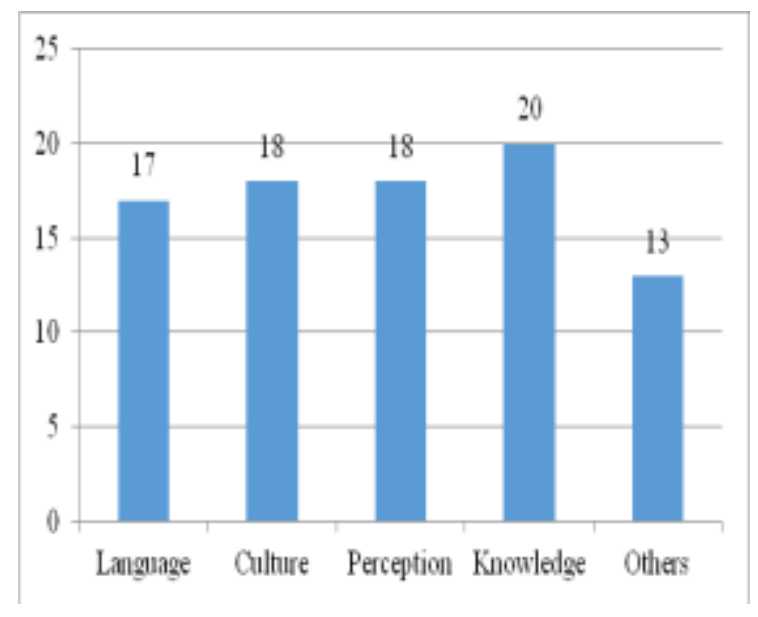

Figure 8: Main factors that influence communication 


\section{DISCUSSIONS ON FINDINGS}

The targeted respondents as the project team members were aware of the implication of effective communication strategies in ensuring project success. Delay in land acquisition caused by oppositions from the community and landowner was severe. The tabulation of results from the respondents' point of view on the severity rate in Figure 4 have shown high weightage on the rating of seriousness. This might be caused by the respondents who had experienced delay issues in managing the overhead power transmission line project. Majority of the respondents have also agreed that the engagement programmes with community and landowner was unsuccessful (Figure 6). From the author's opinion, the existing engagement programmes in the power utilities company such as periodical meetings and CSR were insufficient in tackling this issue due to land acquisition problems.

A strategic communication plan requires coverage from the beginning of the project stage to the operation stage (Roland Berger, 2014). Table 4 proposed communication methods with community and landowner formulated through the project stages to be based on the Roland Berger Online Toolkit. It is proposed that this can be adapted to the construction of high voltage overhead power transmission line projects in Peninsular Malaysia.

It is suggested that the grid owner as the project developer to create project-specific websites to include useful project information in their website. Information have to be made accessible to the public to increase transparency. A project information office should be set up in suitable location that can be visited by the public anytime. The contents of information displayed are important to explain the need for the specific grid development project, the project schedule and information on the project developers and possibilities for the public to get involved and provide input from an early stage.

The project website should contains the surveys or questionnaires to seek public opinion and input in a less formal manner than an official consultation or dialogue. This will aid to portray the project developer's interest in listening and taking public concerns into account. Websites can also be useful to NGOs, the media, political authorities or any other stakeholders involved to publish their view points and potential input and involvement with the project.

Dialogues are to be established with the community and landowner at an early stage of the project. The outcomes from the dialogue and surveyed data from the website are useful source of information of the issues that might occurred during the further development of the project. Dialogues shall be controlled using good interpersonal skills which can reach people heart and enlighten sufficient information needed by the community and landowner. Direct mailings or e-mailings to the community and landowner can ensure that they receive key information and to allow for distribution of targeted text-based or visual material, such as flyers, brochures and fact sheets.

In lieu to the communication method schedule, it is also suggested that a comprehensive task list is prepared to ensure successful implementation of the projects. The followings are the general list proposed for the communication activities with the community and landowner:

a) Planning and preparation of materials,

b) Planning of initial round of meeting, doorstep visit and dialogue,

c) One-on-one meetings with landowner prior to clearing and construction activities,

d) Notify community and landowners prior to start of construction, 
e) Initial round of communication; and

f) Periodic assessment and upgrading of the communication management measure.

As illustrated in Figure 8, the factors which can influenced effective communication strategy were identified. Variables such as language, culture, perception, knowledge and other factors such as political influence can affect communication between these parties involved in overhead power transmission lines. The language barrier in Peninsular Malaysia was due to the differences of language proficiency when the communities such as the Chinese and Indian community were poor at multi-language proficiency. They only speak in their native language and not open to communicate in English language or Bahasa Malaysia (Hill, 2011).

Strategic communication contains the ways to communicate creatively and persuasively to build mutually beneficial long-term relationships between organizations and their publics (Washington State University, 2014). As tabulated in Table 4, the requirements of a strategic communication plan were identified as follows in sequential order of highest rank to the lowest rank by using mean score:

a) Specify the content of messages to be conveyed in the communication tools

b) Identify the external parties affected by the projects before the project begins

c) Define clear objectives and clarify the expected outcomes from the communication activities

d) Evaluate the performance of the communication activities

e) Monitor feedbacks from the affected parties

f) Define the frequency of communication with the identified parties

g) Define the best communication tools (verbal or non-verbal)

Effective communication strategies can generate positive outcomes that will support the progressive development of the construction of high voltage power transmission lines. The outcomes are due to change of behavior from the community and land owner, developing understanding, meeting objectives and to gain satisfaction from the parties involved.

Respondents have suggested additional factors such as the political influence in terms of collaboration with the district administrator and enforcement on the land acquisition act by the authorities. The respondents felt that these miscellaneous factors seemed to be unfair to the landowner. From the author's point of view, this act seemed to protect the public interest rather than an individual interest. For instance, the act permit the power utility company to acquire or to assess to any land concerned for the construction of high voltage power transmission overhead lines.

The severity of public perceptions on the construction of overhead power transmission lines have caused enormous cost and delay. Therefore, this study is outmost essential to determine the attitudes of the stakeholders concerned to understand the determinants of those attitudes in a better way. It is hoped that with a better understanding on the public reactions it will helps to shed some lights in completing these overhead power transmissions lines project in a timely manner. The goal of this study is to provide a useful tool both to comprehend the public reaction towards the construction of overhead power transmisions lines and to propose effective communication strategies for future projects. 


\section{WAYS FORWARD}

For future research, it is suggested to include viewpoints and opinions from the external stakeholders in the study. The landowner and community should be approached to widen the scope of data collection and to ascertain information from different perspective. It will be very helpful if the practices of other countries with respect to transmission line sitting, compensation and public reaction are to be studied. This will help to generate an insight into how other countries such as Japan, Australia, United States and United Kingdom dealt with these issues due to the construction of power transmissions lines. Comparisons study between these countries and Malaysia might yield some unforeseeable advantageous to the current practice in handling disputes.

\section{CONCLUSION}

Project communication plan is one of the priority in any planning and implementation of construction project especially for large infrastructure project such as high voltage overhead power transmission lines project. The implementation and construction of high voltage overhead power transmission lines project is important because various stakeholders such as external stakeholders which comprise of community and landowner are involved. These stakeholders will be affected by the construction of high voltage overhead power transmission lines and some of them are holding the ownership of the vicinity of the proposed transmission corridor. The best solution to manage these stakeholders is through effective communication strategies. Communication is an important vehicle to make people understand the benefit of a project (PMI, 2013).

Language, culture, perception, knowledge and other factors such as political influence are the variables that determine how communication can be performed effectively. The language barrier in Peninsular Malaysia refers to the language proficiency when the communities such as the Chinese and Indian community are concerned. Some Chinese and Indian community are not well versed in communicating in English language or Bahasa Malaysia. Messages that were conveyed in English language or Bahasa Malaysia were not interpreted correctly by the end recipient.

From the author's point of view, perception is developed through experience and it dictates how we look and make justification to certain issue. Educating the relevant parties on the benefits and importance of power transmission lines construction is under the responsibility of the project developer. Political influence on the other hand is an issue that should be taken into consideration in actual set-up of communication plan. In conclusions, effective communication strategies will help to generate positive outcomes which will support the progressive construction of the high voltage overhead power transmission lines. 


\section{REFERENCES}

Alias, A., and Daud, M.N. (2006). Payment of adequate compensation for land acquisition in Malaysia. Pacific Rim Property Research Journal, 12, 326-349.

Babbie, E. (2007). The basics of social research. $4^{\text {th }}$ Ed. Boston, MA, USA: Cengage Learning.

Crawford, C.O. (1955). Appraising damages to land from power line casements. The Appraisal Journal, July, 367-378.

Cresswell, J.W., and Clark, P. (2007). Designing and Conducting Mixed Method Research.

Droge, P., and Messer, P. (2012). European power struggles - Can public resistance be overcome? Energy Technologies Special Report.

Energy Commission (2014). Peninsular Malaysia Electricity Supply Report.

Farley, J.W. (2003). Power lines and cancer : Nothing to fear.

Furby, L., Slovic, P., Fischhoff, B., and Gregory, R. (1988). Public perceptions of electric power transmission lines. Journal of Environmental Psychology, 8, 19-43.

Hill, C.W.L. (2011). International Business: Competing in the Global Marketplace, 8th Ed. New York: McGraw-Hill/Irwin.

Krejcie, R.V., and Morgan, D.W. (1970). Determining sample size for research activities.

Project Management Institute (2013). A Guide to the Project Management Body of Knowledge (PMBOK Guide), 287.

Project Management Institute (PMI). (2013). Communication: the message is clear.

Rathbone, M., and Redrup, O. (2014). Delivering rail projects in Asia. PricewaterhouseCoopers.

Roland Berger Strategy Consultants (2014). Study Regarding Grid Infrastructure Development: European Strategy for Raising Public Acceptance.

Roscoe, J. T. (1975). Fundamental research statistics for the behavioural sciences. New York: Holt Rinehart \& Winston.

Tenaga Nasional Berhad (2007). Annual Report.

Tenaga Nasional Berhad (2013). Annual Report.

Zulkiflee, M.Y., and Sivadass, T. (2006). Construction Management of Power Transmission Lines - Logistics and Challenges, Proceedings of the 6th Asia-Pacific Structural Engineering and Construction Conference (APSEC 2006), 5 - $6^{\text {th }}$ September 2006, Kuala Lumpur, Malaysia. 